\title{
Application of methanotrophic biofilters to reduce GHG generated by landfill in Quebec City (Canada)
}

\author{
N. Turgeon ${ }^{1}$, Y. Le Bihan ${ }^{1}$, G. Buelna ${ }^{1}$, C. Bourgault ${ }^{2}$, \\ S. Verreault ${ }^{3}$, P. Lessard ${ }^{2}$, J. Nikiema ${ }^{4} \&$ M. Heitz ${ }^{4}$ \\ ${ }^{I}$ Centre de recherche industrielle du Québec (CRIQ), Canada \\ ${ }^{2}$ Université Laval, Département de génie civil et de génie des eaux, \\ Quebec, Canada \\ ${ }^{3}$ Ville de Québec, Canada \\ ${ }^{4}$ Université de Sherbrooke, Department of Chemical Engineering and \\ Biotechnological Engineering, Faculty of Engineering, Canada
}

\begin{abstract}
Compared to carbon dioxide $\left(\mathrm{CO}_{2}\right)$, methane $\left(\mathrm{CH}_{4}\right)$ is a strong greenhouse gas (GHG) and landfills are one of the major anthropogenic sources of atmospheric $\mathrm{CH}_{4}$ produced by anaerobic degradation of organic waste. In Canada as in many countries around the world, programs and regulations are implemented to force capture and burning of landfill gas (LFG). However, when thermal oxidation (flaring or energetic valorisation) is not possible (i.e. low $\mathrm{CH}_{4}$ concentration or flowrate), microbial methane oxidation by methanotrophic biofilters represents a new technology that holds great promises for GHG reduction and air pollution control of LFG. Exploratory work done in CRIQ laboratories (Quebec Canada) allowed testing different types of mediums (organic and inorganic) for the design of methanotrophic biofilters. Following this initiative, pilot scale project was undertaken in 2009. The objective was to evaluate, using a prototype installed in a closed landfill (Beauport, Quebec City), the technical and economic feasibility of implantation of methanotrophic biofilter for the treatment of LFG. Testing protocol has been implemented over a period of $83 \mathrm{~d}$ (from September to November 2009). The collected data were used to evaluate conversion rates (up to $80 \%)$ and the maximum elimination capacity $\left(\mathrm{ECmax}=66 \mathrm{~g} \mathrm{CH}_{4} / \mathrm{m}^{3} / \mathrm{h}\right)$. Large-scale technology demonstration work is planned for 2011-2012 to
\end{abstract}


validate, over 12 months, the GHG reduction cost established for methanotrophic biofilter (CAD\$16-20/t $\left.\mathrm{CO}_{2} \mathrm{eq}\right)$.

Keywords: methane, landfill gas, greenhouse gas, methanotrophic bacteria, biofilters, nitrous oxide.

\section{Introduction}

Methane $\left(\mathrm{CH}_{4}\right)$ is a colorless, odourless, flammable gas that has a 100-year global warming potential (GWP) of 21 [1]. Since 1750, the overall average atmospheric concentration of $\mathrm{CH}_{4}$ has increased by $157 \%$ [2]. After carbon dioxide $\left(\mathrm{CO}_{2}\right), \mathrm{CH}_{4}$ is the next most plentiful greenhouse gas (GHG) that can be attributed to human activities (raising livestock, intensive agriculture, industrial processes, extraction of combustible fossil fuels, coal mines, the incomplete combustion of combustible fossil fuels and waste management) [3].

Landfill gases (LFGs) are produced when the organic portion of landfill waste biodegrades in the absence of oxygen. LFGs may contain substantial concentrations of $\mathrm{CH}_{4}$ (up to $55-60 \% \mathrm{v} / \mathrm{v}$ ) and $\mathrm{CO}_{2}(40-45 \% \mathrm{v} / \mathrm{v}$ ) [4]. Figure 1 drawn from Jensen and Pipatti [5] shows a representation of LFG production as a function of time. Methane production continues until the organic waste is completely degraded by methanogenic bacteria, which may take up to 100 years for certain sites. Over the course of the stable production phase of $\mathrm{CH}_{4}$ (i.e., $\sim 20$ years), the produced LFGs may be utilized or incinerated using a flare stack. In Quebec (Canada), capture and incineration are mandatory for sites having a landfill capacity more than 50,000 metric tons/year according to the Regulation Respecting the Landfilling and Incineration of Residual Materials (REIMR) that

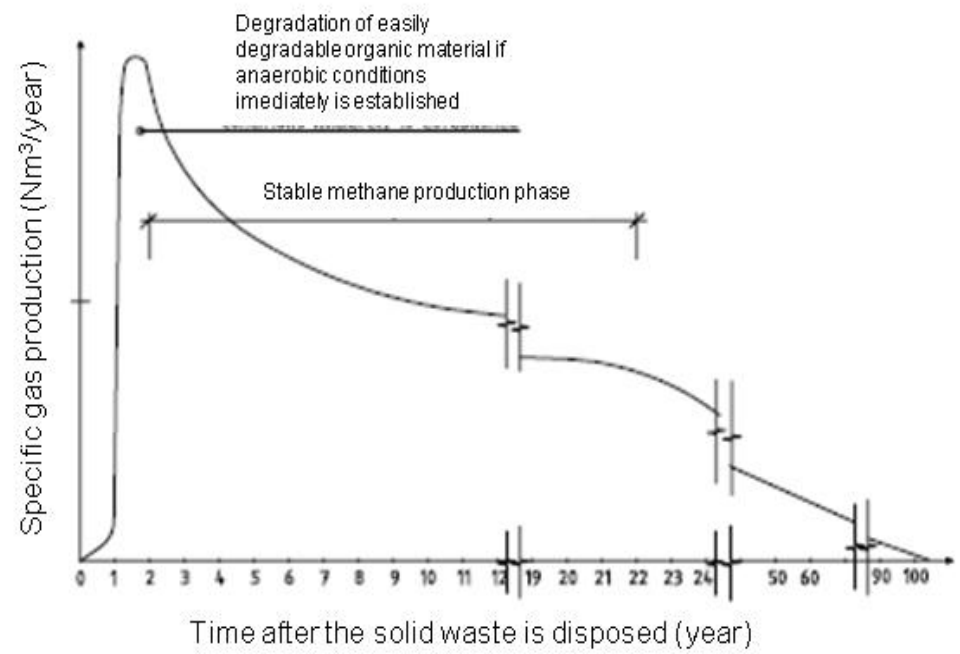

Figure 1: Scholl Canyon model representation of landfill degradation. 
went into effect as part of the Quebec Action Plan 2006-2012 [6]. For other landfill locations (smaller ones or those set up prior to 2006), or when the quality of the LFGs (i.e. $\mathrm{CH}_{4}<25 \%$ by volume) does not allow further thermal oxidation without adding a supplementary gas (propane or natural gas), incineration is not mandatory and the LFGs produced at these locations are generally emitted directly into the atmosphere, thereby generating considerable GHG emissions.

Methanotrophic bacteria belong to a sub-group that falls under the physiological group of methylotrophic bacteria and are unique in their capability to use $\mathrm{CH}_{4}$ as a source of carbon and energy. This characteristic has also been the subject of various studies especially in order to identify the primary environmental factors that govern the biological oxidation process of $\mathrm{CH}_{4}$ (temperature, moisture, oxygen, nitrogen, pH, etc.) [8-13]. Among the biological treatment processes, biofiltration has been for several years a recognized approach for controlling industrial atmospheric emissions such as odours and volatile organic compounds (VOCs) [14-16]. Given the context of fighting climate change, biofiltration of $\mathrm{CH}_{4}$ now appears to be a very promising method to reduce GHGs. This process consists of passing the gas stream to be treated through a filtering bed packed with porous materials on which microorganisms are fixed. Under aerobic conditions, compounds such as $\mathrm{CH}_{4}$ are transformed into molecules that are less harmful to the environment $\left(\mathrm{CO}_{2}, \mathrm{H}_{2} \mathrm{O}\right.$, salts and biomass) according to the biological oxidation reaction described in equation 1 .

$$
\begin{aligned}
& \mathrm{CH}_{4}+\alpha \mathrm{O}_{2} \rightarrow \beta \mathrm{CO}_{2}+\delta \mathrm{H}_{2} \mathrm{O}+\text { Cells, with } \alpha \leq 2, \beta \leq 1, \delta \leq 2 \\
& \Delta \mathrm{G}^{0}=-780 \mathrm{~kJ} \mathrm{~mol}^{-1} \mathrm{CH}_{4}
\end{aligned}
$$

Contrarily to passive oxidation systems (e.g., landfill biocovers), methanotrophic biofilters are engineering reactors where conditions such as the concentration of $\mathrm{CH}_{4}$, air flow rate, humidity, temperature, $\mathrm{pH}$, inoculation, and dosage with nutrients are controlled especially to ensure higher and more stable elimination capabilities and conversion rates. A review of the literature by Nikiema [17] made it possible to identify about 20 published studies bearing specifically on the biofiltration of methane. Most of these projects were performed in laboratories (prototype) with synthetic gases (mixture of natural gas and compressed air). Exploratory work conducted in laboratories (30-liter biofilters) has enabled various types of filter bed (organic and inorganic) pertaining to biofilter design [18] to be tested. Based on this experimentation, a technological demonstration project was carried out in collaboration with Quebec City in 2009. The primary objective of this project was to evaluate the technical-economic feasibility of establishing a biofiltration process to treat LFGs and reduce GHG emissions by means of a prototype installed at a landfill site. 


\section{Material and methods}

\subsection{Description of the Beauport Landfill Site (Quebec, Canada)}

According to the greenhouse gas emissions balance performed in 2007 for the Quebec City metropolitan area, the Beauport landfill site contributes $\sim 8 \%$ of the total GHG emissions of the City's corporate inventory (i.e. $\sim 18,000 \mathrm{t}$ $\mathrm{CO}_{2}$ eq/year). Beauport is a closed site where 918,000 metric tons of waste were buried between 1979 and 1986. In 2005, a capture system was installed to control LFG migration toward neighbouring homes and businesses. Since then, the LFGs captured in this way $\left(\sim 240 \mathrm{~m}^{3} / \mathrm{h}, \mathrm{CH}_{4}=3 \%\right.$ to $\left.18 \% \mathrm{v} / \mathrm{v}\right)$ have been discharged into the atmosphere without any treatment.

\subsection{Description of the Biofiltration Prototype}

The technological demonstration projects were carried out over a period from July to November 2009. The experimental biofiltration prototype used for these tests was installed directly at the Beauport site, near the existing LFG pumping station (Figure 2:). This prototype consisted primarily of a pre-filter (500 mm x $600 \mathrm{~mm} \times 1,400 \mathrm{~mm}$ ) equipped with atomization nozzles to ensure humidification of the gas stream, a fan followed by a Biosor ${ }^{\mathrm{TM}}$ biofilter $(950 \mathrm{~mm}$ x 1,000 mm x 1,000 mm) with organic filter (mixture of peat moss and wood chips) (Figure 3:). Two reservoirs, each with a volume of $350 \mathrm{~L}$, made it possible to recover by means of gravity the scrubbing water (pre-filter) and the nutrient solution (biofilter), and then to recycle these effluents using centrifugal pumps.

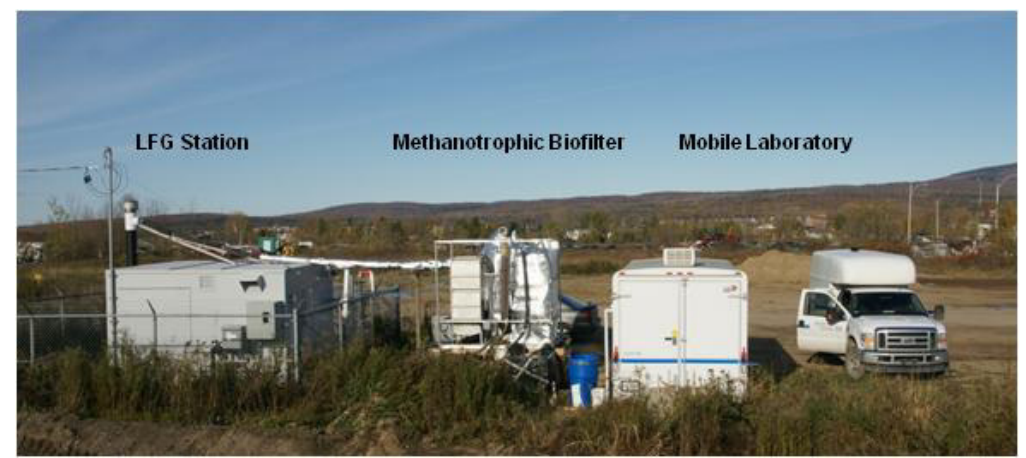

Figure 2: $\quad$ Experimental setup (closed landfill Beauport, Quebec City).

Laboratory-cultivated methanotrophic bacteria were applied by liquid inoculation directly on the biofilter's medium. The dosed addition of nutrients (N, P, oligoelements) necessary for methanotrophic bacteria to grow was performed by incorporating slow-dissolving granulated fertilizer directly into the biofilter or added as needed to the reservoir containing the nutrient solution. 
1

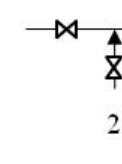

3

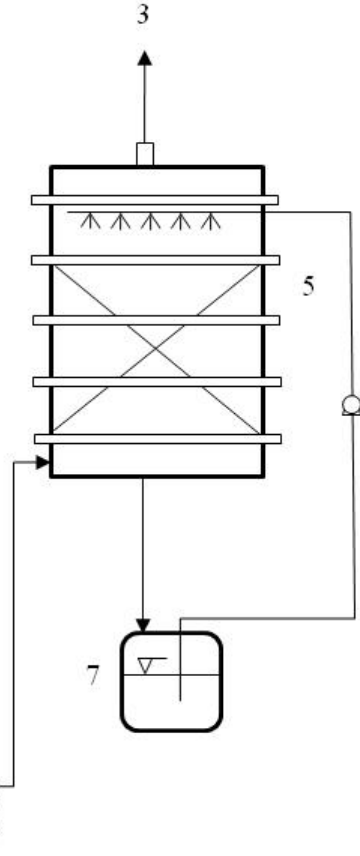

Figure 3: Flow chart of pilot scale Methanotrophic Biofilter. 1-LFG from biogas station; 2-ambient air; 3-exhaust; 4-conditioning chamber; 5-methanotrophic biofilter; 6-water; 7-nutrient solution.

The biofiltration system was started on July 24, 2009. However, problems pertaining to air infiltration at the ventilator were noted in early September. Testing was re-started on September 3, 2009 and continued up to November 25, 2009 (total duration: 83 days).

\subsection{Analytical monitoring}

Characterizing the primary GHGs $\left(\mathrm{CH}_{4}, \mathrm{~N}_{2} \mathrm{O}\right.$, and $\left.\mathrm{CO}_{2}\right)$ was performed using a multi-gas analyzer and gas chromatography using a flame ionization detector equipped with an automatic sampling system (GC-FID Varian 3800). This device was installed on site inside a mobile laboratory for the duration of the tests.

The parameters used to describe the results are defined in table 1 , namely the inlet load (IL) in $\mathrm{gCH}_{4} / \mathrm{m}^{3} / \mathrm{h}$, the $\mathrm{CH}_{4}$ conversion rate (X) in $\%$ and the elimination capacity (EC) in $\mathrm{gCH}_{4} / \mathrm{m}^{3} / \mathrm{h}$.

The temperature of the LFGs and the biofilters was monitored using RTD sensors connected to an automatic data acquisition system (DAQ PRO-5300, EQ-3015). 
Table 1: Determination of the quantitative parameters.

\begin{tabular}{cc}
\hline Parameters & Methods of determination \\
\hline $\mathrm{IL}:$ Volumetric inlet load $\left(\mathrm{gCH}_{4} / \mathrm{m}^{3} / \mathrm{h}\right)$ & $\mathrm{IL}=\frac{\mathrm{C}_{\left(\mathrm{CH}_{4}\right) \text { in }} \times \mathrm{Q}}{\mathrm{V}}$ \\
$\mathrm{X}$ : Conversion (\%) & $\mathrm{X}=\frac{\mathrm{C}_{\left(\mathrm{CH}_{4}\right) \text { in }}-\mathrm{C}_{\left(\mathrm{CH}_{4}\right) \text { out }}}{\mathrm{C}_{\left(\mathrm{CH}_{4}\right) \text { in }}} \times 100$ \\
$\mathrm{EC}:$ Elimination capacity $\left(\mathrm{gCH}_{4} / \mathrm{m}^{3} / \mathrm{h}\right)$ & $\mathrm{EC}=\mathrm{IL} \times \mathrm{X}$ \\
\hline $\begin{array}{l}\text { Concentration in } \mathrm{gCH}_{4} / \mathrm{m}^{3} ; \mathrm{Q}=\text { Volumetric flow of } \mathrm{LFG} \mathrm{in} \mathrm{m}^{3} / \mathrm{h} ; \mathrm{V} \text { : Biofilter volume in } \\
\mathrm{m}^{3}\end{array}$
\end{tabular}

\section{Results and discussion}

\subsubsection{Characterization of the LFGs}

Table 2 depicts the characteristics of landfill gas captured and discharged at the LFG station during the testing period. The relatively high concentration of oxygen ( 7 to $9 \% \mathrm{v} / \mathrm{v}$ ) reveals the presence of air infiltration in the Beauport site's capture network. Calculating the direct GHG emissions shows that the LFG station discharges about $1,270 \mathrm{t} \mathrm{CO}_{2}$ eq/year into the atmosphere, or about $7 \%$ of the total annual emissions modeled for the Beauport site.

Table 2: $\quad$ LFG characterization.

\begin{tabular}{cc}
\hline Period & July 24,2009 to Nov. 24,2009 \\
Flow & Average: $165 \mathrm{Nm}^{3} / \mathrm{h}\left(141\right.$ to $\left.192 \mathrm{Nm}^{3} / \mathrm{h}\right)$ \\
Temperature & 30 to $40^{\circ} \mathrm{C}$ \\
$\mathrm{CH}_{4}$ & $6.4 \%(1.7$ to $13.1 \% \mathrm{v} / \mathrm{v})$ \\
$\mathrm{CO}_{2}$ & $4.1 \%(2.6$ to $13.1 \% \mathrm{v} / \mathrm{v})$ \\
$\mathrm{N}_{2} \mathrm{O}$ & $3 \mathrm{ppmv}(0$ to $8 \mathrm{ppmv})$ \\
$\mathrm{O}_{2}$ & 7 to $9 \% \mathrm{v} / \mathrm{v}$ \\
\hline
\end{tabular}

\subsubsection{Monitoring the Biofiltration Prototype}

Figure 4: depicts the elimination capacity (EC) as a function of the inlet load (IL). The data points represented by $\diamond$ correspond to the start-up phase of the biofiltration process (Sept. 4, 2009 to Sept. 14, 2009), or about 10 days. The data points represented by correspond to the loading phase of the biofiltration prototype. The results obtained show an average conversion rate $\left(\mathrm{X}_{\text {average }}\right)$ of $53 \%$ and a maximum $\left(\mathrm{X}_{\max }\right)$ going up to $80 \%$. The maximum elimination capacity $\left(\mathrm{EC}_{\max }\right)$ recorded over the course of testing was $66 \mathrm{~g} / \mathrm{m}^{3} / \mathrm{h}$ for an inlet load (IL) of about $95 \mathrm{~g} / \mathrm{m}^{3} / \mathrm{h}$. These results are comparable to the best purification performance identified by Nikiema et al. [19]. 


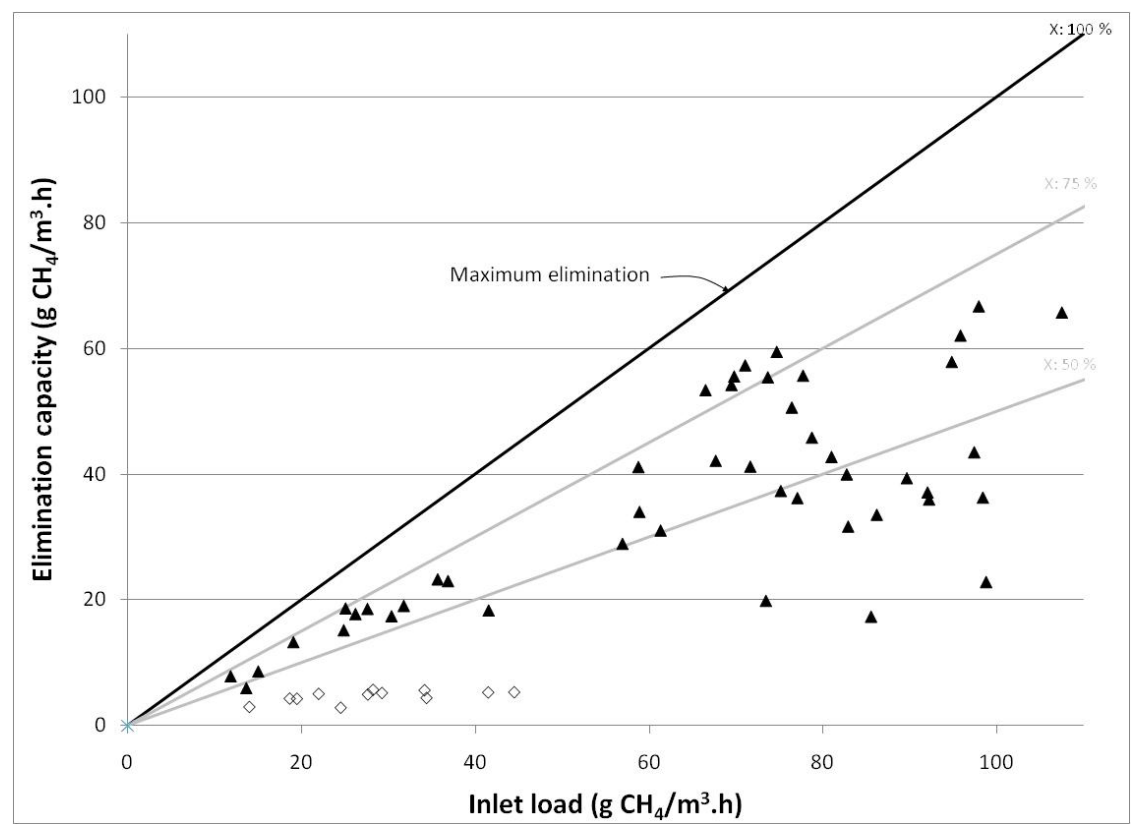

Figure 4: $\quad$ Elimination capacity (EC) as a function of $\mathrm{CH}_{4}$ inlet load (IL).

Figure 5: depicts the trend of the temperature in the middle of the filter bed (uninsulated biofilter) and the inlet concentration of $\mathrm{CH}_{4}$ as a function of time. Over the first 30 days of operation (month of September), the concentration of $\mathrm{CH}_{4}$ at the biofilter's inlet was maintained at $<2 \% \mathrm{v} / \mathrm{v}$ (i.e., 20,000 ppmv) by adjusting the flow rate of the diluting ambient air. Then, the dilution valve was closed until the end of testing to treat the non-diluted LFGs. An increase of the $\mathrm{CH}_{4}$ concentration at the biofilter's inlet was accompanied by a significant and spontaneous increase of the biofilter's temperature (from 35 to $60^{\circ} \mathrm{C}$ ) due to the exothermic $\mathrm{CH}_{4}$ degradation process. Temperatures exceeding $50^{\circ} \mathrm{C}$ within the biofilters were also noted during the studies under similar operation conditions [20]. In early November, a drop in temperature was recorded from 55 to $25^{\circ} \mathrm{C}$. This cooling of the biofilter was associated with a decrease in the exterior temperature as well as a lack of nutrient solution causing a decrease in the $\mathrm{CH}_{4}$ conversion rates. These results show that the bio-oxidation of $\mathrm{CH}_{4}$ is highly dependent on temperature and nutrients. Accordingly, these parameters represent two important indicators pertaining to the operation of the methantrophic biofiltration process.

The biological treatment processes may generate nitrous oxide $\left(\mathrm{N}_{2} \mathrm{O}\right)$ emissions due to an incomplete nitrogen transformation process [21, 22]. Figure 6 depicts the presence of $\mathrm{N}_{2} \mathrm{O}$ at the biofilter's outlet with concentrations varying between 3 and 307 ppmv (average: 97 ppmv). Since $\mathrm{N}_{2} \mathrm{O}$ is a powerful GHG $(\mathrm{GWP}=310)$, it is important to consider these direct emissions when quantifying the process's GHG reductions (section 3.1.3). 


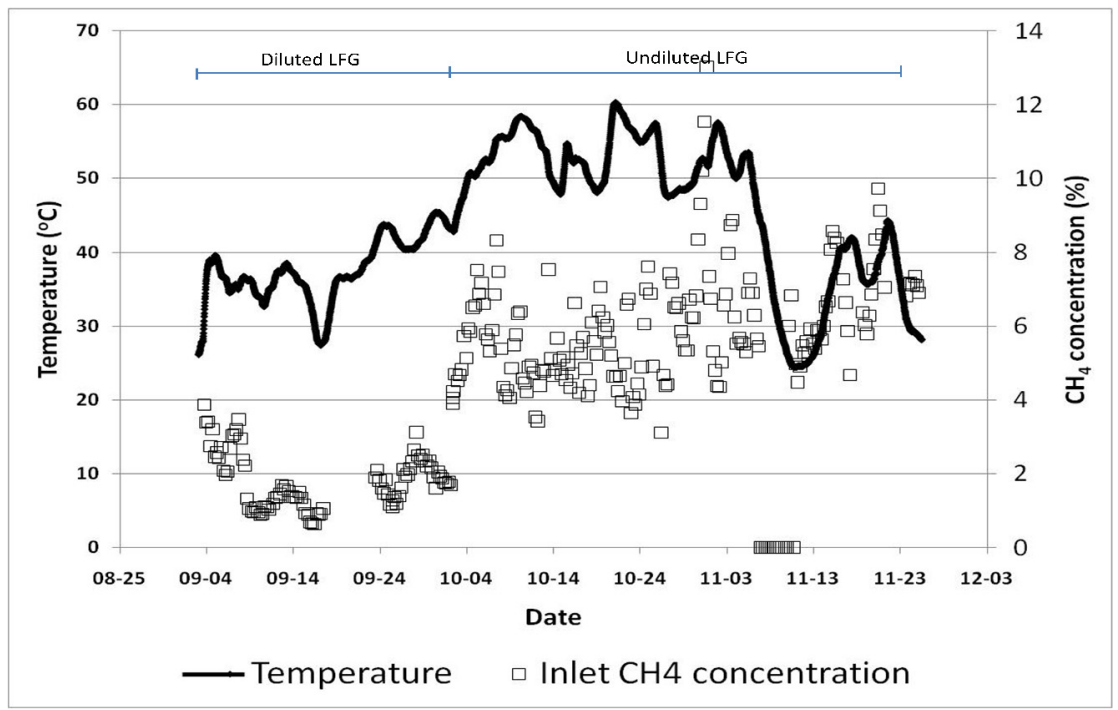

Figure 5: $\quad$ Inlet $\mathrm{CH}_{4}$ concentration and temperature of biofilter.

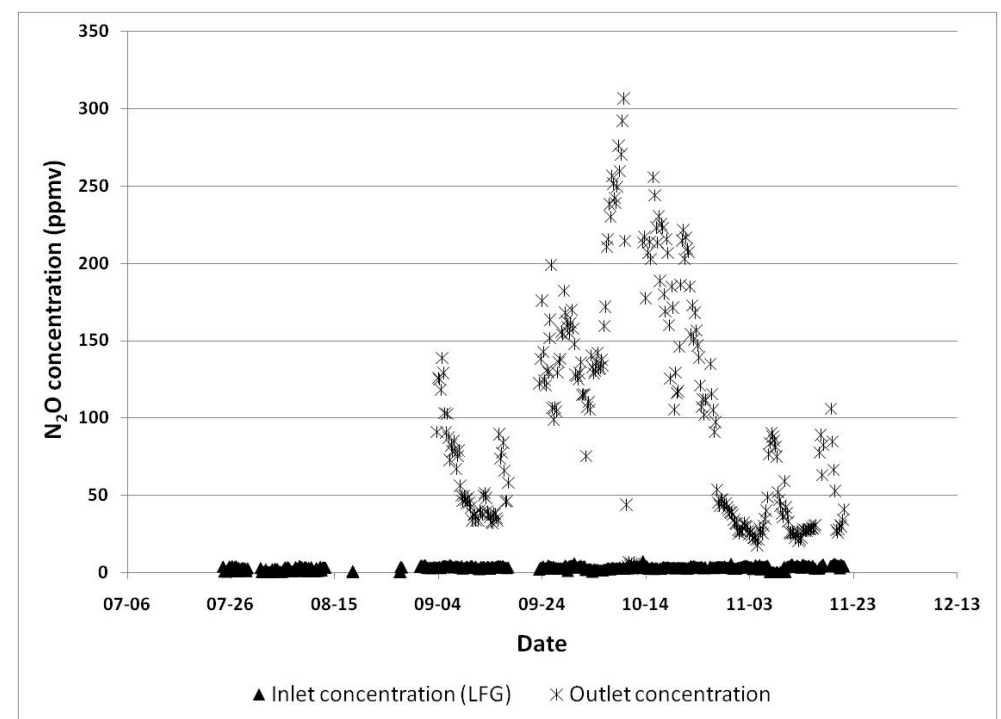

Figure 6: $\quad$ Monitoring of nitrous oxide $\left(\mathrm{N}_{2} \mathrm{O}\right)$ concentration.

\subsubsection{Evaluating the costs associated with reducing GHG emissions}

Table 3 shows an established scenario for calculating the costs associated with reducing GHG emissions using Biosor $^{\mathrm{TM}}$ methanotrophic biofiltration technology in Quebec (Canada). When considering a site already equipped with LFG capture systems, the unit costs for reducing GHGs is estimated to be about CAD\$16-20/t $\mathrm{CO}_{2}$ eq. 
Table 3: GHG's emission reducing cost: Methanotrophic Biofilter.

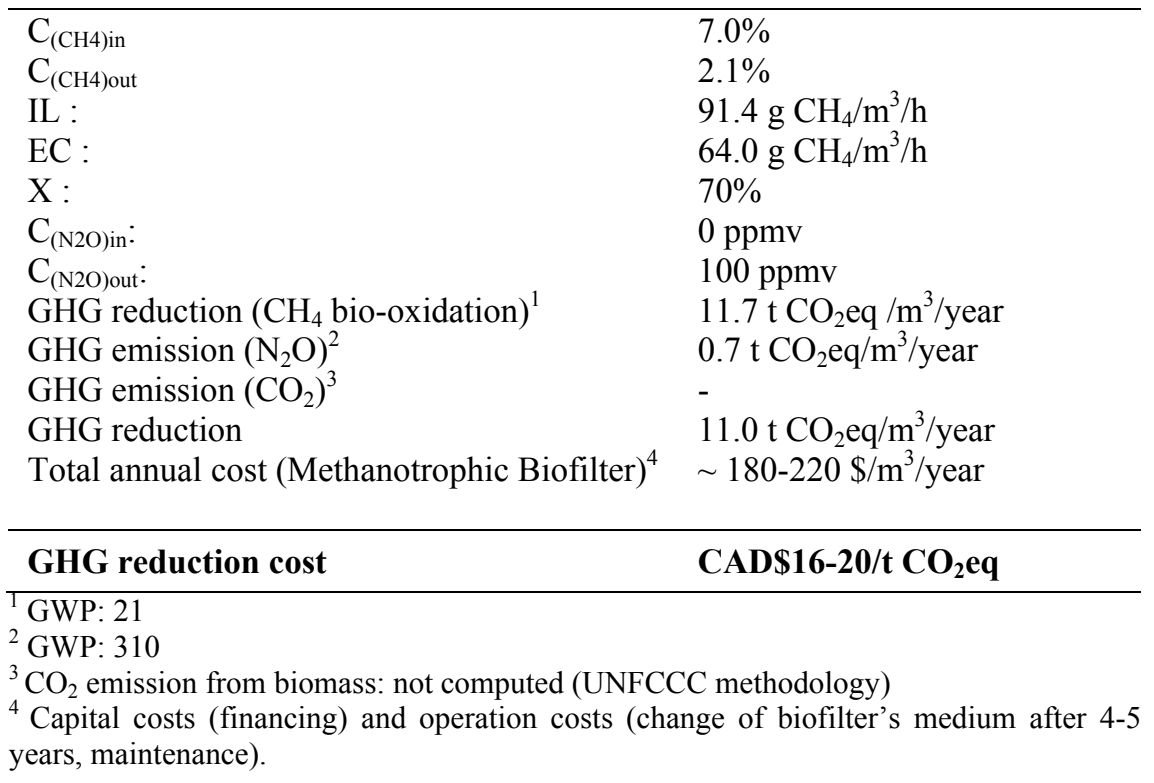

\section{Conclusion}

This project's primary objective was to validate the technical and economic feasibility of Biosor ${ }^{\mathrm{TM}}$ biofiltration technology to treat $\mathrm{CH}_{4}$ and reduce GHGs generated by landfill gas (LFG) emissions originating from a site that has been closed for more than 15 years. A biofiltration prototype equipped with a monitoring system was thus installed at the Beauport landfill site (Quebec, Canada) and monitored for a period of 83 days. The results obtained enabled one to establish the technology's conversion rates $\left(\mathrm{X}_{\max }: 80 \%\right)$ as well as a maximum elimination capacity $\left(\mathrm{EC}_{\max }: 66 \mathrm{~g} / \mathrm{m}^{3} / \mathrm{h}\right.$ for an inlet load of $\left.95 \mathrm{~g} / \mathrm{m}^{3} / \mathrm{h}\right)$. Monitoring the biofilter's temperature constitutes a significant and simple indicator for the process's proper functioning. The reduction costs associated with implementing a methanotrophic biofilter in a landfill site already equipped with a capture system were estimated to be about CAD $\$ 16-20 / t \mathrm{CO}_{2}$ eq. Fullscale demonstration projects are planned in order to validate that, in a Nordic climate situation, biofiltration constitutes a robust and cost-effective alternative for treating LFGs and reducing GHG emissions.

\section{Acknowledgements}

This project was completed subsequent to agreements between Centre de recherche industrielle du Québec (CRIQ), Université Laval and Université de Sherbrooke, and made possible thanks especially to the financial participation of CRIQ's internal research program and the City of Quebec. 


\section{References}

[1] Intergovernmental Panel on Climate Change (IPCC). Climate Change 1995: The Science of Climate Change. Summary for Policymakers and Technical Summary of the Working Group I Report. p. 22. Cambridge (UK): Cambridge, University Press, 1995.

[2] World Meteorological Organization. WMO Greenhouse Gas Bulletin: Main Greenhouse Gases Reach Highest Level Ever Since Pre-Industrial Time. November 2009. No. 868. Available online at: http://www.wmo.int /pages/mediacentre/press_releases/pr_868_en.html

[3] Solomon, S., Qin, D., Manning, M., Chen, Z., Marquis, M., Averyt, K.B, Tignor, M. and Miller, H.L., Climate Change 2007: The Physical Science Basis, Contribution of Working Group 1 to the Fourth Assessment Report of the Intergovernmental Panel on Climate Change (IPCC), Cambridge (UK): Cambridge University Press, 2007.

[4] Environment Canada, National Inventory Report 1990-2008, Part 1: Greenhouse gas sources and sinks in Canada, The Canadian Government's Submission to the UN Framework Convention on Climate Change, 2010.

[5] Jensen, EF, Pipatti, R., $\mathrm{CH}_{4}$ Emissions from Solid Waste Disposal, February 2003. Available online at: http://www.ipccnggip.iges.or.jp/public/gp/bgp/5_1_CH4_Solid_Waste.pdf

[6] Le Québec et les changements climatiques, un défi pour l'avenir. Plan d'action du Québec 2006-2012 sur les changements climatiques. Juin 2008. Disponible en ligne à:

[7] http://www.mddep.gouv.qc.ca/changements/plan_action/2006-2012_fr.pdf

[8] Humer, M., Lechner, P., Microbial methane oxidation for the reduction of landfill gas emission, Journal of Solid Waste Technology and Management, Volume 27, NOS 3 \& 4, November 2001.

[9] Dammann, B., Steese, J., Stregmann, R., Microbial oxidation of methane from landfills in biofiltres, Proceedings Sardinia 99, Seventh International Waste Management and Landfill Symposium, S Margherita di Pula, Cagliari, Italy, 4-8 October 1999.

[10] Park, S.Y., Brown, K.W., Thomas, J.C., The use of biofiltres to reduce atmospheric methane emissions from landfills: Part 1. Biofilter Design, Water, Air, and Soil Pollution, 155: 63-85, 2004.

[11] Haubrichs, R., Widmann, R., Evaluation of aerated biofilter systems for microbial methane oxidation of poor landfill gas, Waste Management, 26: 408-416, 2006.

[12] Nikiema, J., Heitz, M., The use of inorganic packing materials during methane biofiltration, Hindawi Publishing Corporation, International Journal of Chemical Engineering, Article ID 573149, 8 pages, Volume 2010

[13] Scheulz, C., Bogner, J. E., De Visscher, A., Gelbert, J., Hilger, H. A., Huber-Humer, M., Kjeldsen, P., Spokas, K., Microbial methane oxidation processes and technologies for mitigation of landfill gas emissions, Waste management \& research, Volume 27, Issues 5, August 2009. 
[14] Devinny, J.S., Deshusses, M.A., Webster, T.S., Biofiltration for Air Pollution Control. Lewis Publishers, Boca Raton, Florida, 1999.

[15] Kennes, C., Veiga, M.C., Bioreactors for Waste Gas Treatment. Kluwer Academic Publishers, 312 p., 2001.

[16] Delhoménie, M.-C., Heitz, M., Biofiltration of Air: A Review, Critical Reviews in Biotechnology, 25:1-20, 2005.

[17] Nikiema, S. J., Atténuation des émissions de gaz à effet de serre par biofiltration du méthane : optimisation des paramètres opératoires, thèse de doctorat ès sciences appliquées, Université de Sherbrooke, 2008.

[18] Turgeon, N., Bourgault, C., Buelna, G., Le Bihan, Y., Verreault, S., Lessard, P., Nikiema J., Heitz, M., Développement d'un procédé de biofiltration pour le traitement du $\mathrm{CH}_{4}$ et la réduction des GES, Salon des technologies environnementales du Québec, Centre des Congrès de Québec (Québec, Canada), 16 mars 2010.

[19] Nikiema, J., Brzezinski, R., Heitz, M., Elimination of methane generated from landfills by biofiltration: a review, Rev. Environ. Sci. Biotechnol, 6:261-284, 2007.

[20] Steese, J., Stegmann, R., Design of biofilters for methane oxidation, Proc. Sardinia 2003, Ninth International Waste Management and Landfill Symposium, S. Margherita di Pula, Cagliari, Italy; 6 -10 October 2003.

[21] Czepiel, P., Crill, P., Harriss, R., Nitrous Oxide Emissions from Municipal Wastewater Treatment, Environ. Sci. Technol., 29 (9), pp 2352-2356, 1995

[22] Kimochi, Y., Inamori, Y., Mizuochi M., Xu K.-Q., Matsumura M., Nitrogen removal and $\mathrm{N}_{2} \mathrm{O}$ emission in a full-scale domestic wastewater treatment plant with intermittent aeration, Journal of Fermentation and Bioengineering, Volume 86, Issue 2, pp 202-206, 1998. 